\title{
Serum electrolytes and lipid profiles in non-insulin dependent diabetes mellitus patients
}

\author{
Namama Talabani \\ Department of Chemistry, Faculty of Science, University of Sulaimania, Kurdistan, Iraq
}

\section{A B S T R A C T}

Background: Diabetes mellitus and hyperlipidemia are the most common metabolic disorder affecting the people all over the world. Hyperglycemia is considered a primary cause of diabetic vascular complications and is associated with impaired electrolytes in some of the metabolic dysfunctions is not clear. Aim: The purpose of this study was conducted to investigate the relationship among diabetes mellitus, lipid profiles and electrolytes $\left(\mathrm{Na}^{+}, \mathrm{K}^{+}\right.$ and $\mathrm{Cl}^{-}$). Methods: In the sera of 85 non insulin-dependent diabetes mellitus NIDDM, 45 with hyperlipidemia, 40 without hyperlipidemia, 50 samples of hyperlipidemia without NIDDM, and 50 non diabetic healthy control subjects. The mean age of the diabetic patients was similar to that of control.The mean duration of the disease was (10.2 \pm 5.9$)$ years (2-23) years. From the results, it was discovered that there was a significant decrease in $\mathrm{Na}^{+}$and $\mathrm{Cl}^{-}$in patients with NIDDM without high level of lipid profile (group I), but our results show that the concentration of $\mathrm{K}^{+}$not changed significantly. The plasma levels of $\mathrm{Na}^{+}$and $\mathrm{Cl}^{-}$ions were show significant change in patient with hyperlipidemia without NIDDM (group II), while plasma $\mathrm{K}^{+}$not changed significantly in this group as compared with control. The mean value of $\mathrm{Na}^{+}$and $\mathrm{Cl}^{-}$show high significant change in NIDDM patients with high level of lipids profile (group III), were plasma $\mathrm{K}^{+}$not changed significantly as compared with control group. Conclusion: These finding may explain the role of impaired electrolytes status in NIDDM and hyperlipidemia subjects.

Key words: Type-Il diabetic mellitus, Hyperlipidemia, Electrolytes
Access this article online

Website:

http://nepjol.info/index.php/AJMS

DOI: 10.3126/ajms.v6i3.11088

\section{INTRODUCTION}

Diabetes mellitus DM is heredity, chronic and endocrine metabolic disorder which causes death worldwide. ${ }^{1}$ Type 2 diabetes is associated with cluster of interrelated plasma lipid and lipoprotein abnormalities, including reduced HDL cholesterol, predominance of small density LDL particles and elevated triglycerides., ${ }^{2,3}$

There are probably 100 million people in the world with diabetes mellitus and incidences of diabetes are on the rise. As diabetes progress patients are at increased risk of developing coronary disease. ${ }^{4,5}$

NIDDM is directly linked with dyslipidemia due to the lack of effect of insulin. Altered atherogenic lipoprotein pattern and elevation of some liver enzymes have been identified as independent risk factors for the development of cardiovascular disease along with prevalence of liver enzymes abnormality ranging from 7.2 to $22.9 \%$ in patients of NIDDM. ${ }^{6-8}$

Infact, pre-diabetic individuals often exhibit an atherogenic pattern of risk factors that includes higher levels of total cholesterol, LDL cholesterol, triglycerides and lower levels of HDL cholesterol than individuals who do not develop diabetes. ${ }^{9,10}$

In case where a disease such as diabetes disrupts metabolic function, the body's electrolyte control system is broken down. The results of electrolyte imbalance can be severe.

In diabetic out patients, acid-base and electrolyte disorders occurred often even if the renal function is normal, and the most common disorders are metabolic alkalosis and 
metabolic acidosis, in addition, the common electrolyte disorders are hypernatremia and hypokalemia. ${ }^{11}$

\section{MATERIALS AND METHODS}

This study was conducted at the department of chemistry, Faculty of Science with collaboration of Central Medical Lab in Suliamania city, Kurdistan region/Iraq.

\section{The study group}

This study was conducted on 3 groups: group I, II and III. The patients were diagnosed on the basis of detailed clinical history, clinical examination and other relevant biochemical investigations. The patients suffering from other diseases, such as diabetes, inflammatory diseases, hepatic impairment, cardiac diseases and other systemic diseases. Fasting venous blood were drawn from all.

\section{Collection of blood samples}

After an overnight fasting of 10-12 hours, about $5 \mathrm{ml}$ of whole blood was collected via vena puncture with the help of a disposable syringe in between 8.00-9.00 am.

Glucose detected by enzymatic reaction (glucose oxidase and peroxidase $=$ GOD-POD) ${ }^{12}$

Different lipid fractions were estimated along with fasting plasma glucose. Serum total cholesterol was determined by an enzymatic (CHOD-PAP) colorimetric method, ${ }^{13}$ triglycerides were determined by an enzymatic (GPO-PAP) method, ${ }^{14} \mathrm{HDL}$-cholesterol was estimated by a precipitant method, ${ }^{15}$ LDL-cholesterol was estimated by using Friedewald formula. ${ }^{16}$

LDL-cholesterol $=$ Total cholesterol- $(\mathrm{HDL}$ cholesterol+triglycerides $/ 5$ )

Serum analysis for fasting $\mathrm{Na}^{+}, \mathrm{K}^{+}$and $\mathrm{Cl}^{-}$was performed by the automatic analyzer, ROCHE module Cobas 6000 (C-501 and C-601), and kits were procured by ROCHE.

Statistical analysis was carried out using standard deviation and chi-square test from which $(\mathrm{P})$ value was derived. The $P$ value $<0.05$ was considered to be significant.

\section{RESULTS}

The mean \pm SD age of patients was 39.98 \pm 3.91 (range 25-55) while the mean \pm SD of control was $40.02 \pm 1.41$ (23-57) years. Out of 85 patients $45(55 \%)$ were male and $40(45 \%)$ were females. Among control subjects $25(50 \%)$ for female and males, with mean of duration of the disease (10.2 \pm 5.9$)$ years (Table 1).
Descriptive statistics of all diagnostic parameters on group I, II and III presented in Tables 2-4.

Table 2 show the mean total cholesterol, triglycerides, HDL-Cholesterol, LDL-Cholesterol and fasting blood sugar levels (group I), the patients in this group have NIDDM syndrome with normal values of lipid profiles. The mean levels of serum $\mathrm{Na}^{+}(128.2 \pm 3.1 \mathrm{meq} / \mathrm{L})$ were significantly lower in the sera of NIDDM in comparison to the control subjects $(140.09 \pm 2.33 \mathrm{meq} / \mathrm{L})$, the mean level of $\mathrm{K}^{+}(4.21 \pm 0.34 \mathrm{meq} / \mathrm{L})$ show non significance change in this group, while serum $\mathrm{Cl}^{-}(110.16 \pm 5.54 \mathrm{meq} / \mathrm{L})$ increased significantly in the sera of NIDDM patients in comparison to that of control subjects $(95.08 \pm 0.08 \mathrm{meq} / \mathrm{L})$.

Table 3 show the mean total cholesterol, triglycerides, HDL-Cholesterol, LDL-Cholesterol and fasting blood sugar levels (group II), the patients in this group have normal blood sugars with hyperlipidemia syndrome. The mean levels of serum $\mathrm{Na}^{+}(118.2 \pm 3.13 \mathrm{meq} / \mathrm{L})$ were significantly lower in the sera of hyperlipedimia syndrome in comparison to the control subjects $(140.09 \pm 2.33 \mathrm{meq} / \mathrm{L})$, the mean level of $\mathrm{K}^{+}(4.41 \pm 0.74 \mathrm{meq} / \mathrm{L})$ show non significance change in this group, while serum $\mathrm{Cl}^{-}(89.26 \pm 0.54 \mathrm{meq} / \mathrm{L})$ decreased significantly in the sera of hyperlipidemic patients in comparison to that of control subjects $(95.08 \pm 0.08 \mathrm{meq} / \mathrm{L})$.

Table 4 show the mean total cholesterol, triglycerides, HDL-Cholesterol, LDL-Cholesterol and fasting blood sugar levels (group III), the patients in this group have

\begin{tabular}{lcc}
\multicolumn{3}{l}{ Table 1: Age and sex distribution of study } \\
\hline Age range & $\begin{array}{c}\mathbf{2 5 - 5 5} \text { years } \\
\text { (patients) }\end{array}$ & $\begin{array}{c}\mathbf{2 3 - 5 7} \text { years } \\
\text { (control) }\end{array}$ \\
\hline Mean $\pm S D$ & $39.98 \pm 2.91$ & $40.02 \pm 1.41$ \\
Sex distribution & $45(55 \%)$ & $25(50 \%)$ \\
$\quad$ Male & $40(45)$ & $25(50 \%)$ \\
$\quad$ Female & $10.2 \pm 5.9$ years & $2-23$ years \\
Duration of disease & & \\
\hline
\end{tabular}

\begin{tabular}{|c|c|c|c|}
\hline Parameters & Case & Control & Significance \\
\hline Bl.glucose $\mathrm{mg} / \mathrm{dl}$ & $357.91 \pm 15.19$ & $95.21 \pm 8.91$ & $\mathrm{HS}$ \\
\hline Triglyceride $\mathrm{mg} / \mathrm{dl}$ & $178.03 \pm 9.12$ & $169.32 \pm 10.42$ & NS \\
\hline Cholesterol mg/dl & $155.52 \pm 12.05$ & $160.41 \pm 14.64$ & NS \\
\hline HDL-Chole mg/dl & $40.12 \pm 0.54$ & $38.22 \pm 7.10$ & NS \\
\hline LDL-Chole mg/dl & $113.59 \pm 5.91$ & $112.65 \pm 4.65$ & NS \\
\hline $\mathrm{Na}^{+} \mathrm{Meq} / \mathrm{L}$ & $128.2 \pm 3.1$ & $140.09 \pm 2.33$ & $S$ \\
\hline $\mathrm{K}^{+} \mathrm{Meq} / \mathrm{L}$ & $4.21 \pm 0.34$ & $4.66 \pm 0.05$ & NS \\
\hline $\mathrm{Cl}^{-} \mathrm{Meq} / \mathrm{L}$ & $110.16 \pm 5.54$ & $95.08 \pm 0.08$ & $S$ \\
\hline
\end{tabular}




\begin{tabular}{|c|c|c|c|}
\hline Parameters & Case & Control & Significance \\
\hline Bl.glucose mg/dl & $97.54 \pm 13.29$ & $95.21 \pm 8.91$ & NS \\
\hline Triglyceride $\mathrm{mg} / \mathrm{dl}$ & $289.83 \pm 12.22$ & $169.32 \pm 10.42$ & HS \\
\hline Cholesterol mg/dl & $395.52 \pm 16.65$ & $160.41 \pm 14.64$ & HS \\
\hline HDL-Chole mg/dl & $61.12 \pm 0.54$ & $38.22 \pm 7.10$ & HS \\
\hline LDL-Chole mg/dl & $195.55 \pm 7.46$ & $112.65 \pm 4.65$ & $\mathrm{HS}$ \\
\hline $\mathrm{Na}^{+} \mathrm{Meq} / \mathrm{L}$ & $118.2 \pm 3.13$ & $140.09 \pm 2.33$ & HS \\
\hline $\mathrm{K}^{+} \mathrm{Meq} / \mathrm{L}$ & $4.41 \pm 0.74$ & $4.66 \pm 0.05$ & NS \\
\hline $\mathrm{Cl}^{-} \mathrm{Meq} / \mathrm{L}$ & $89.26 \pm 0.54$ & $95.08 \pm 0.08$ & $\mathrm{~S}$ \\
\hline
\end{tabular}

NS: no significance, HS: high significance, S: significance

\begin{tabular}{|c|c|c|c|}
\hline Parameters & Case & Control & Significance \\
\hline Bl.glucose mg/dl & $402.91 \pm 15.19$ & $95.21 \pm 8.91$ & HS \\
\hline Triglyceride mg/dl & $327.03 \pm 7.11$ & $169.32 \pm 10.42$ & HS \\
\hline Cholesterol mg/dl & $295.52 \pm 10.05$ & $160.41 \pm 14.64$ & HS \\
\hline HDL-Chole mg/dl & $41.15 \pm 0.50$ & $38.22 \pm 7.10$ & $S$ \\
\hline LDL-Chole mg/dl & $213.00 \pm 4.01$ & $112.65 \pm 4.65$ & HS \\
\hline $\mathrm{Na}^{+} \mathrm{Meq} / \mathrm{L}$ & $127.52 \pm 3.21$ & $140.09 \pm 2.33$ & HS \\
\hline $\mathrm{K}^{+} \mathrm{Meq} / \mathrm{L}$ & $4.21 \pm 0.34$ & $4.66 \pm 0.05$ & NS \\
\hline $\mathrm{Cl}^{-} \mathrm{Meq} / \mathrm{L}$ & $85.26 \pm 4.14$ & $95.08 \pm 0.08$ & HS \\
\hline
\end{tabular}

NS: no significance, HS: high significance, S: significance

NIDDM syndrome with hyperlipidemia. The mean levels of serum $\mathrm{Na}^{+}(127.52 \pm 3.21 \mathrm{meq} / \mathrm{L})$ were significantly lower in comparison to the control subjects $(140.09 \pm 2.33 \mathrm{meq} / \mathrm{L})$, the mean level of $\mathrm{K}^{+}(4.21 \pm 0.34 \mathrm{meq} / \mathrm{L})$ show non significance change in this group, while serum $\mathrm{Cl}^{-}(85.26 \pm 4.14 \mathrm{meq} / \mathrm{L})$ decreased significantly in comparison to that of control subjects $(95.08 \pm 0.08 \mathrm{meq} / \mathrm{L})$.

\section{DISCUSSION}

The incidence of diabetes mellitus in the community is $5-10 \% \cdot{ }^{17,18}$ Diabetes mellitus damages every organ in the body, mainly the kidneys, leading to end-stage renal diseases. ${ }^{19-21}$

The patients suffering from diabetes mellitus have disturbances in the electrolytes and in the acid-base balance. These distribution are caused by the diabetes (glucose balance), renal diseases and medications (diuretics and calcium channel blockers). ${ }^{22}$

The potassium levels in IDDM and in NIDDM patients were reduced during periods of poor control of diabetes mellitus and increases when the blood glucose level are normal, ${ }^{23}$ the levels of potassium were reduced because of diuretics ${ }^{24}$ as well as due to diabetic keto acidosis (increased loss in urine). This explains the existence of hydrovolemia in these patients. We verified the presence of hyperkalemia and because of this metabolic acidosis can occur frequently in these patients.

Diabetic usually take medication that influences the electrolyte balance. Thus, loop diuretics and thiazides may cause hyponatremia, hypokalemia and deficiency of magnesium, disturbances in calcium handling (increased renal loss with loop diuretics and re absorption by thiaxides) and hyperglycemia. The treated NIDDM patients may continue to have mild hypertriglycridemia, increased intermediate-density lipoprotein levels, small dense lowdensity lipoprotein LDL with increased apolipoprotein B, and decreased HDL cholesterol levels. The central and abdominal distribution of adipose tissue in IDDM (insulin dependent diabetic mellitus) is associated with insulin resistance, hypertension, and the above lipoprotein abnormalities. Improvement in glucose control, in the absence of weight gain, leads to lower triglyceride and higher HDL cholesterol levels. In addition, the diabetic patient is prone to develop other defects that, in themselves, leading to hyperlipidemia, such as proteinuria, hypothyroidism and hypertension. ${ }^{25}$

\section{REFERENCES}

1. Faghilimni S, Hashemipour M and Kelishadi B. The lipid profile of children with type 1 diabetes as compared to the controls. ARYA Journal 2006; 2(1):36-38.

2. American Diabetes Association: Management of dyslipidemia in adults with diabetes (position statement). Diabetes Care 2003; 26(suppl.1):S83-S86.

3. Ronald M and Krauss MD. Lipid and lipoproteins in patients with type 2 Diabetes. Diabetes Care 2004; 27(6); 1496-1504.

4. World health organization Expert committee on prevention and treatment of diabetes mellitus WHO technical series No 844 Geneva World Health Organization (1994).

5. Spratt KA. Managing diabetic dyslipidemia Aggressive approach. $\mathrm{J}$ of the American Osteopathic Association 2009;109:2-7.

6. Marco RD, Lacatelli F, Zappini G, Verlato G, Bonora E and Muggeo M. Cause specific Mortality in type 2 Diabetes-the Verona Diabetes study. Diabetes Care 2000;22:756-761.

7. Elizabeth $\mathrm{HH}$. Elevated liver function tests in type 2 Diabetes. Clinical Diabetes 2005;23:115-119.

8. Balaji AS, Suhas BJ, Ashok MA and Mangesh T. Serum Alanine Transaminases and lipid profile in type 2 Diabetes Mellitus Indian patients. Journal of Research in Diabetes 2013; Article TD 613176,30 minipages.

9. Haffner SM, Mykkanen L, Festa A, Burke JP and Stern MP. Insulin -resistant prediabetic subjects have more atherogenic risk factors than insulin- sensitive prediabetic subjects: implications for preventing coronary heart disease during the prediabetic state. Circulation 2000;101:975-980.

10. Haffner SM, Stern MP, Hazuda HP, Mitchell BD and Patterson JK Cardiovascular risk factors in confirmed prediabetic individuals: does the clock for coronary heart disease start ticking before the onset of clinical diabetes? JAMA 1990; 263:2893-2898. 
11. Sotirakopoulos N, Kaloqinnidou I, Tersi M, Armentzioiou K, Sivridis D and Mavromatidis K. Acid-base and electrolyte disorders in patients with diabetes mellitus. Saudi Journal of Kidney Disease and Transplantation 2012; 23(1):58-62.

12. Jietz N.W. Fundamentals of clinical chemistry $2^{\text {nd }}$ edition. W.B.Saunders Co,Toronto (1982)

13. Allain CC, Poon IS, Chan CHG and Richmond W. Enzymatic determination of serum total cholesterol. Clinical Chemistry $1974 ; 20: 470-471$.

14. Jacobs NJ and Van Denmark PJ. Enzymatic Determination of serum triglycerides. Biochemical Biophysical 1960; 88:250-255.

15. Gordon T and Gordon M. An Enzymatic method for the determination of the serum HDL-Cholesterol. America Journal of Medicine 1977; 6:707-708.

16. Friedewald WT, Levy RI and Fredrickson DS. Estimation of the concentration of LDL-Cholesterol. Clinical Chemistry 1972; 18(6):499-515.

17. Schales $O$ and Schales SS. A simple and accurate method for determination of chlorides in biological fluids. Journal Biological Chemistry 1941;140:79-82.

18. Garancini MP, Calori G, Ruotola G, Ruotolo G, Manara E, Izzo A, et al. Prevalence of NIDDM and impaired glucose tolerance in Italy: an OGTT-based population study. Diabetologia 1995; 38(3):306-313.

19. Harris MI, Flegal KM, Cowie CC, Ebrhardt MS, Goldstein DE,
Littile RR, et al. Prevalence of diabetes, impaired fasting glucose and impaired glucose tolerance in U.S adults. The third National Health and Nutrition Examination survey. 1988-1994. Diabetes Care 1998;21(4):518-524.

20. Bojestig M, Arnqvist HJ, Hermansoon G, Karlberg BE and Ludvigsson J. Declining incidence of nephropathy in insulindependent diabetes mellitus. NEJM 1994; 330(1):15-18.

21. Frei $U$ and Schober-Halstenberg HJ. Annual report of the German renal registry 1998. Quasi-Niere task group of Quality Assurance in renal replacement therapy. Nephrol Dialysis Transplanatation 1999;14(5):1085-1090.

22. Amenabar JJ, Garcva- Lapez F and Robles NR. 1997 Spanish nephrology association. (Sociedad Espaoola de nefrologia) report on dialysis and transplantation. Nephrol Dialysis Transplantation 1999;14(12):284-285.

23. Zawada ET. Metabolic considerations in the approach to diabetic hypertensive patients. America Journal of medicine 1989; 87(6A):S34-S38.

24. Walsh $\mathrm{CH}$, Soler NG, James H, Harvey TC, Thomas BJ and Fremlin $\mathrm{JH}$. Studies in whole body potassium and whole body nitrogen in newly diagnosed diabetics. Oxford journal medicine and health 1976; 45(178):295-301.

25. Abbate SL and Brunzell JD. Pathophysiology of hyperlipidemia in diabetes mellitus. Journal of Cardiovascular pharmacology 1990; 16(9):S1-S7.

Authors Contribution:

NT: Conceived, design of the study, collected and analyzed the data, manuscript preparation and review of the final edition of manuscript.

Source of Support: Nil, Conflict of Interest: None declared. 